\title{
A Move toward Learner-Centred Foreign Language Pedagogy: Focusing on Factors Fostering Language Intake
}

\author{
Dana Hanesova
}

DOI: 10.18355/XL.2015.08.04.46-59

\begin{abstract}
The author presents an account of two investigations $(2000,2015)$ of variables that seem to play a role in students' turning language input into language intake. This process can be considered the first step toward successful learning of foreign languages. In the first part of the study the theoretical base of this issue is described, especially the notion of language intake as well as the broader concept of learnercentred language pedagogy. Various theories designate various factors as important in the process of language intake. The two sets of research data collected via observation of an experimental implementation of a new ESP (English for Specific Purposes) course show the most important factors influencing the successful process of language intake. In the end of the study, the author presents a list of cognitive, affective, cognitive and physical variables that were found while observing the learners during their learning (such as the learner's pre-knowledge and linguistic repertoire, motivation, emotional barriers, and rapport with the teachers, as well as adequate teaching form and positive climate).

Key words

learner-centred, pedagogy, foreign language, input, intake, variables
\end{abstract}

\section{Introduction}

As data from several research studies on the implementation of learnercentred instruction (Huba \& Freed, 2000; McCombs, 2003; Allen, 2004; Kember, 2009; ESU-report, 2011; Geven \& Attard, 2012; Crumly, 2014 etc.) show, learnercentred teaching is only very slowly becoming school reality. The teacher-centred paradigm has been deeply rooted throughout the Central European education systems. Though the first challenges to transform it into learner-centred education (indicated already in learner-focused research by Piaget, Vygotsky or Rogers) emerged more than half a century ago and since then hundreds of studies have been written about the topic, many teachers still seem to be reluctant to incorporate the theory of learner autonomy into their everyday practice. Could it be that current language teachers also need to reflect on their teaching-learning paradigm first before investing huge amounts of energy in preparing lots of interesting activities using the most modern technologies and procedures?

In our study we decided to reflect our own foreign language teaching from the learner's point of view. After an overview of theoretical outcomes, this study presents and compares two sets of selected data acquired from two distinctive investigations completed by the author over a period of 15 years. The purpose for doing so was to investigate at least some factors influencing the process taking place between the language input provided by a teacher/curricula/ textbooks and the actual language intake accomplished by learners. Based on the reflection of these data some clues for more steps toward learner-centredness in foreign languge teaching are indicated.

\section{Learner-centredness as the current paradigm of foreign language pedagogy}

Although it may sound like a cliché, learner-centred instruction/education has been proved as indisputably more effective compared to teacher-centred education. 
Although there is no space here to refer to the rich body of research confirming this statement, the fact is that learner-centred teaching has come under the spotlight in European educational policy and thus has become a challenge for all teachers. The European educationalists consider so called student-centred learning (SCL) to be an approach to education which aims at overcoming some of the problems inherent in more traditional forms of education by focusing on the learners and the processes connected with their part in the teaching-learning process, rather than being centred around the teacher's input. This approach has many implications for the design and flexibility of curriculum, course content, and interactivity of the learning process and is being increasingly used at universities across Europe. The signatories of the Communique of the Ministerial Meeting of the Bologna Process in Leuven in 2009 expressed their support for student-centred learning and mobility because of its role in developing the competencies students need in a changing labour market and in empowering them to become active and responsible citizens. Also, educators in other regions, such as in Canada and the USA, have been underlining the need to invest more effort in researching learning processes rather than only teaching processes. Weimer (2012), in her introduction to her Learner-Centred Teaching, argues that university teachers had for years been addressing the process of developing teaching skills while ignoring the process of students' learning. Not only that, but "the previous disconnect between teaching and learning has proved counterproductive" (p. xii). In a lot of countries, specific features and good-practice examples of successful learnercentred instruction have not yet been documented in a satisfactory way.

Obviously, what has been just said applies to all teaching contexts, including institutional foreign language courses. The basic premise is that they can be really effective only if their teachers a) are aware of the specifics of both complementary processes - teaching as well as learning; and b) concentrate consciously on the principles of the learning process in their professional performance. Learner-centred language teachers view students' learning not as a rotation of distinctive language training activities, but holistically as an authentic deliberate social act. Only subsequent to reflection on this learner-centred paradigm are they able to begin their conscious, purposeful projection of how the learners themselves can reach the aims of the lesson or course. Teachers' traditional emphasis on distinctive skills, grammar and on assessment for summative purposes is properly balanced by their careful attention they pay to the selection of adequate methodology activating learning strategies (e.g. Vasbieva, 2015: 63), cooperative group work, problem-based learning and formative assessment. Thus language learners can be empowered to become actively engaged in their own language learning, starting with their involvement in formulating the course objectives. Subsequently their autonomy lies in their conscious mastering their learning objectives via their own acquisition of new information and its processing.

\section{The importance of language intake in learner-centred foreign language pedagogy}

From the perspective of EFL (foreign language teaching) methodology, there is a logical connection between learner-centredness and learner's language intake and output. Based on an intersection of definitions by educational, psychological and neurological theories, foreign language learning can be viewed as a process of construction of language knowledge, including the knowledge of the associated culture (Birova, 2013; Zelenkova, 2015), by integrating new language learning content into learners' previous knowledge. It is a process of transformation of language input provided by teachers/course materials into language output produced by the learners. To do that effectively - as it has been documented by several authors (Corder, 1967; Hatch, 1983; Carroll, 2001; Rast, 2008; Pawlak, 2011; Chaudron 1983; 
Gagliardi, 2012; Reinders, 2012 and others) - it is necessary first to focus on the transition process (as well as product) between input and output - the language intake. In Krashen's terminology, it is the input that reached the language acquisition device (1982: 32).

So, generally, learning languages can happen only after input becomes intake. There exist various definitions of these terms, the existence of both input and output theories speaks for all. As the primary aim of this study is to describe some preconditions of effective language intake based on research, the following paragraphs present only an overview of some definitions of these concepts, not a systematic study of their nuances.

Input includes "stimuli that have entered the brain" (Carroll, 2001). These are the potentially processable language data which are made available and coming "by chance or by design, to the language learner. It comes from a kind of source (teachers, textbook, hidden curriculum ...)" (Sharwood Smith, 1993: 167) in the direction of the 'black box' of the learning mechanism of students. The fact is that generally the brain of the learner is able to process and turn into output only a portion of all inserted information. The most important first step toward reaching the expected results out of the 'black box' of an individual's learning process is his/her process of selecting what to take in from all the offered input. Corder already in 1967 expressed the necessity to distinguish these two by defining "input as that what is 'available' for going in" and intake what actually 'goes in' the learner's knowledge bank and thus it is controlled by the learner. According to Rast (2008: 3), this definition of intake was extended by Hatch's definition (1983) as 'a successful and complete' process, achieving the building up of internal memory of the learners, in comparison to input, which is only a 'partially successful' process.

Language input is all the language that the learner is exposed to in his/her environment (e.g. Trosborg, 1995: 68) . According to Putz and Sicola (2010: 3), it is a linguistic phenomenon available to learners through not only their aural, but also their visual systems. Speaking about the effective language learning, verbal linguistic expression should always be understood as "only one facet" of the process. It is necessary also to consider the other, non-verbal channels of communication. "In the context of second language learning, the combination of verbal and non-verbal stimuli is seen as being pivotal to providing the learner with the necessary communicative elements that will engender better learning ... transforming of input into intake " (p. $3)$.

Language intake is a subset of the input language set that caught the learner's real attention, contained a strong enough incentive to be processed by him or her and thus contributed to building internal understanding of the language. It means the learner's perception and processing of target language input. Intake is being viewed from three perspectives: as a product, as a process, and or as a combination of the two (Reinders, 2012: 23).

Neurological researchers (e.g. in Sato \& Jacobs, 1992) have been attempting to investigate the brain processes explaining the intake during foreign language learning. Intake is connected to the ability of the brain to process the linguistic data from the input and hold them in working memory for further processing (e.g. VanPatten, 2002). Also, according to some, e.g. Pawlak (2011) and Reinders (2012: 28 ), intake is a subset of detected input, "held in short-term memory, from which connections with long-term memory are potentially created or strengthened."

\section{Variables Affecting Language Intake}

Language intake is a complex process consisting of considering and comprehending new information in the context of one's previous language and 
cultural experience, knowledge and schemes, and finding their meaning. The extent of the success of the language intake depends on the amount of attention paid to the input, the strength of existing connections, as well as learning aptitude and a whole range of other factors as revealed by recent research (e.g. Janikova, 2015: 54-71).

One of the most important presumptions of language intake is that "the language must be presented in a form that can be processed by the learner" (Trosborg, 1995: 69). This includes the age relevance - children tend to neglect language that is far beyond their level. E.g. Gagliardi (2012: 250) described processes involved in acquisition of a new grammar rule. Through her research she found that the "evidence of incomplete encoding (as witnessed by the poor fit between the input and what children learn) highlights the necessity of separating what is accessible to the learner given his or her linguistic and cognitive abilities from what is available (in principle) in the input." Foreign language learning of adults learners has some specific, distinctive features which play a significant role in the input - intake process.

In the case of adult language education, holistic attention has to be paid to all dimentions of adult language needs:

- $\quad$ cognitive (level of mastering the foreign language, general inteligence..)

- $\quad$ affective (motivation, interests, attitudes, self-evaluation, worries)

- $\quad$ physical (pain, tiredness)

- $\quad$ social (position in the classroom).

According to the input and intake theories (e.g. in Dale - Es - Tanner, 2011: 19-20), language learning happens only if the input is comprehensible, meaningful and authentic, and when it is on a slightly more advanced level than the current level of learner's foreign language competence (' $i+1$ ' by Krashen, 1982). It is the meaningfulness - not the form - of the utterance that triggers the attention of the learner's brain (also Sousa, 2006: 39). In other words, learners take in the new input when they understand it, come across it frequently enough (e.g. during learning activities) and have some time to process it. Of course, as Trosborg (1995) comments on this claim, it is provocative for foreign language pedagogy because of the limitations of its formal instruction context. Meaningfulness is best achieved via language courses where language is considered as a means of communication. Such a course is focused on a specialized set of content, e.g. in case of CLIL or ESP (English for Specific Purposes), having double aims - besides the linguistic and communicative skills it is the mastery of the selected content.

Krashen, in 1982, paid careful attention to the affective filter preventing the input from reaching the acquisition device and thus preventing intake from happening. He listed three categories of affective variables and attitudes that function as a filter in the 'acquisition' of second languages: motivation of the learner, self confidence and anxiety (1982: 31). Neurological research has been confirming that feelings effect reasoning and memory. "When the brain network connections are awash with emotion chemicals, synapse strength is modified and the responsiveness of neuron networks be dramatically changed" (according to Zull 2014: 70). Learner's self-concept is another determinant of efficient information processing (Sousa, 2006: 39).

In his overview of intake factors influencing the success of the learning process, Kumaravadivelu (1994: 35) mentions 10 potential sources of perceptual mismatch between teacher intention and learner interpretation applicable also in foreign language pedagogy:

Cognitive - ability of the learner to comprehend the specialized content

- Communicative - communication strategies, skills to exchange messages

- Linguistic - learner's "linguistic repertoire (syntactic, semantic and pragmatic knowledge of the target language)

- $\quad$ Pedagogic - ability to recognize the aims of the educational activities 
- $\quad$ Strategic - learning strategies

- Cultural - prior knowledge of cultural norms

- Evaluative - ways of learner's self-evaluation and monitoring his/her performance (language

- $\quad$ Procedural - learner's tactics/strategies how to reach an aim

- Instructional - instructions "indicated" by the teacher/textbook how to reach the aims

- Attitudinal - learner's attitudes toward the target language and its learning.

From the biological and neurological point of view, there is a necessity of symbiosis of four factors for learning to happen: cognition, control, pleasure and elimination of fear. The adult learner's brain is especially sensitive to the richness of the input content. Zull (2002) warns teachers before putting too much stress on creativity, activity without facts/substance. The amount and quality of offered cognition content has to go hand in hand with the level of control given to the students, elimination of fear and pleasure saturation. Several studies (summarized in Pillar, n.d.) have shown that "language learners learn better when all their senses and emotions are engaged through the global emotional activity of "seeing and hearing" (v celom článku) E.g. Sousa (2006: 39) in his information (which is input) processing model describes that the information has to pass first the sensory register of the learner and then its further success is determined by the meaning and learner's selfconcept.

Before finishing this part, one more point for teachers needs to be stressed here - the importance of learners' prior knowledge analysis before exposing the learners to input. As Ausubel already said back in 1968 (p. iv): "If I had to reduce all of educational psychology to just one principle, I would say this: The single most important factor influencing learning is what the learner already knows." Brain research on learning has been verifying it via observing neuronal networks which are results of learner's life experience, success, fear etc. They are the evidence of the individual's prior knowledge (Zull, 2002: 92). There are various ways of finding them out, e.g via music, images, different forms of languages. So the teachers have "to find ways to build on existing neuronal networks" (Zull, 2002: 100) as they open the door to effective intake. Zull recommends that educators construct the input while keeping the concrete, physical world of the learners in mind." Abstract input has "less meaning if no neuronal networks are associated with the concrete experience of the learner" (ibid.: 103). Teachers cannot do the learning; they can only prepare the conditions for it. Instead of teachers talking and explaining, they should prepare for the students a lot of opportunities, such as problem solving, group work, project work, demonstrations, metaphors, and stories. They have the potential to guarantee the learners the time necessary for recognizing challenging but meaningful content, firing their neural connections, and producing positive intrinsic motivation, all of which lead to their voluntarily internalizing the input by reflecting on it, returning to it and practicing it. Teaching techniques have a greater chance for success if they are selfrewarding in the perception of the learner (Zull, 2002; Brown, 2001).

\section{Quantitative and Qualitative Research of 'Intake' Variables}

Before exploring the preconditions of successful intake to research, let us create a brief summary of all variables that could potentially be explored on the learners' side. First, it is necessary to investigate the role of all three components of mind that might play a role in the intake process (though it is difficult to separate them sometimes) (Huitt, 1999):

- Cognitive - the process of coming to know and understand (What is the meaning of this?), the mental capacity of the learner, general intelligence, the level of mastering the foreign language and the content, the ability to comprehend some 
specialized text and its content (encoding, storing, processing, retrieving). It means the a) prior level of linguistic competence (communication strategies, skills to exchange messages, learner's linguistic repertoire - syntactic, semantic and pragmatic knowledge of the target language); b) prior knowledge of content and its cultural context; and c) cognitive metastrategies (pedagogic ability to recognize the aims of the educational activities, procedural strategies how to reach an aim, strategic learning strategies, assess means of the learner's self-evaluation and monitoring his/her performance;

- Affective - emotional interpretation of perceptions, information, knowledge (How do I feel about this knowledge or information?), interests, attitudes toward the target language and its learning, self-evaluation, self-confidence, worries, elimination of fear, pleasure, values, empathy, optimism;

- Volitional - directed effort, will, striving (Why to do it?) - connection of knowledge and affect towards behaviour (what are my goals, what am I going to do, what are my commitments), becoming aware of one's own needs, visions, dreams and possibilities, making choices, setting goals and making plans, decision, commitment, intentions, control issues, proactive aspect of behaviour, motivation of behaviour, freedom to make decisions or choices, habits, interests, self-direction, self-efficacy, self-regulation.

Besides these learning of students might also be influenced by the physical state of the students (pain, tiredness) as well as by the social role and relationships (e.g. towards the teacher and the peers) in the classroom, and other social groups.

Data about factors preconditioning language learning were gathered during two distinctive investigations. Both of them were carried out in a context of experimenting with newly set-up specialized courses of English for Specific Purposes (ESP) of social sciences students at the Faculty of Education. The time difference between both studies was 15 years which allows to look for some indications of changes or similarities. The first set of data was gathered in years 2000-2001. The learning processes of a group of 15 students of the Faculty of Education, University of Matej Bel were observed during two terms of an ESP course (26 teaching weeks), tailor made for them after a precise needs analysis (according to Nunan, 1996; Polok, 2014: 19, Horvathova, 2011: 32). The second research was carried out during one semester of an ESP course (13 teaching weeks) in spring 2015, taught to a similarly big group of students.

Both courses under the title "From Learning Facts to Learning to Think" (Hanesova, 2014) had two parallel strategic educational aims. The first one was a linguistic aim focused on the development of communicative competence and performance of students, the second one focused on the development of higher thinking skills (according to Bloom's Taxonomy - its Revised Version, 2001). Based on these, three operational goals were established: a) communicative - to reach statistically significant development of communicative competence of students; b) cognitive - to comprehend and master various strategies and techniques for developing critical and creative thinking skills with the English language as their communication medium; and c) socio-affective - to develop significant changes in attitude toward their own language learning and the language course setting.

A rather extensive quantitative and qualitative data set was acquired from the 2000/2001 sample (Hanesova, 2003) not only via observation of verbal and nonverbal communication between the teacher (native American) and students, but also via entrance questionnaires, pre-tests and post-tests (of previous content knowledge, linguistic proficiency test, psychological tests of performative motivation, critical and creative thinking skills, tests of learning styles, brain dominance, extrovercy/introvercy), diarries, interviews, students portfolios and several kinds of 
projections. The research confirmed three hypotheses. Statistical results initially showed correlations between students' intelligence quotient and their outputs. Also the correlation between students' linguistic learning results (reading comprehension) in the target foreign language (English) and their level of reading comprehension in their mother language was confirmed. The investigation proved also the third hypothesis investigating the feasibility of this ESP course, mainly the amount, structure and quality of its input (both linguistic and content). It was proved that the students acquired a statistically significant measure of input in comparison with their pre-knowledge and pre-course level of communication skills in the target language. In conclusion, generally it can be said that the input invested in this 26 week long ESP course was processed into intake and even into output to the expected degree.

Though this statement might sound overly optimistic, such a generalization has its limitations. To be able to see the role and weight of individual factors in the intake and even output process requires more detailed analyses of observation sheets and individual student's output records.

The comparison of measured cognitive variables associated with individual students while entering the course and their learning outcomes showed that the input was actually not as balanced and well-suited to this specific group of individuals as the statistical average might indicate. In fact the students whose entrance level of linguistic competence was higher (e.g. B2 or B2+) showed lower, statistically less insignificant growth $(60 \%)$ at the end of the course compared with those at levels B1, B2- (more than $100 \%$ growth in their linguistic competence). This was the first sign indicating that the level of linguistic input was not cognitively challenging enough for the whole group, at least not for the linguistically stronger students. According to the students' feedback on the meaning of the content input, the same can be said about the content knowledge. A detailed analysis of the connection between each individual student's variables and their outcome revealed that - as a whole, the input was not stimulating and demanding enough. Its meaning did not catch the attention of the more advanced students; in fact, in two cases it caused stagnation in their language development. Because most of the course was carried out in the form of a teacher's lecture, students would have preferred more active methods of delivering the content of the course. It did not stimulated their performance motivation and intake process. The detailed results thus confirmed that the pre-course analysis of the individual learner's cognitive variables and previous knowledge is a must to guarantee that the process of intake and subsequent output will be successful. After that - and only after that - the curriculum should be carefully refined around a reasonably higher level of input (i+1 as Krashen suggested).

The second area of research analysis was focused on the volitional variables. In the researched group no significant correlation appeared between students' ouputs and their level of performance motivation or style of learning. One possible explanation for this result might be that even the output tests were not challenging enough with the result that even students with lower levels of anxiety as a positive motivation element could manage them.

In spite of this, further analysis of affective variables revealed even more about the intake factors. Thanks to audio recordings and field notes of the observers, both the verbal and non-verbal behaviour of all the students was available to analysis and to counting the ratio between them. Using various axes of analyses this way to observe learners has been recommended by several researchers (e.g. Fleming, 1987: 120) because it can disclose data about the real complexity of the learning situation in the classroom which are normally hidden from the eyes of outsiders. Out of 2269 recorded distinctive behavioural episodes (without accounting for the duration of the episodes), categorized into 28 groups, $81 \%$ could be categorized as positive attitudes 
towards this compulsory course integrating language and content and its input (expressed via positive emotions, e.g. smiling; evidencing interest, e.g. writing notes in English out of one's own initiative, actively responding to challenges and questions, active communication in the group, volunteering, etc.; expressions of agreement and enjoyment of the input). The rest (19\%) were episodes expressing criticism or negative perception (non-verbal facial expressions of disagreement, boredom, disappointment, fatigue, whispering, complaining, etc.) of the students. If it had been multiplied by the duration of, e.g. expressions of boredom or lethargy during exposure to listening to lectures, it would have raised this number even more toward the end of students' passive behaviour. On the other hand, when observing the classroom climate as a whole, the majority ( $83 \%$ ) of signals coming from the group were positive, with only $17 \%$ negative signals.

The above-mentioned results data were complemented by statements from students' evaluations during and at the end of the course. Together they gave 186 positive and 127 negative feedback responses. The content of the input was evaluated positively by half of the course attendants in 37 statements, describing it as interesting and stimulating, suitable for improving their learning strategies and professional skills, whereas the other half of the students considered it to be non-practical or too abstract. With reference to evaluations of the linguistic input, students were more appreciative of its focus on development of their specific vocabulary, listening and reading skills. Some of them would have liked more focus on grammar, writing and interaction skills. Students explicitely criticised long lectures, a few also missed more elaborate written assignments suchas essays. Always when the teacher decided to substitute lecturing for other teaching techniques, such as problem solving, brainstorming, listening to life stories etc., students showed their contentment (except for 2 students). Most of the students were not systematically preparing for the course at home which, again, confirmed the observation that the course demanded too low a level of input.

The students also commented on their passivity or active involvement during the course. For about $82 \%$ of them the main hindrance in deciding to invest their energy toward acquiring the input, processing it and transforming it into output was the content of the course itself. They were not used to communicating about the topic of the course, implying that the course did not really get their full attention as it was not based on any perceived information gap. For $4 / 5$ of the students, the course input was imposed from outside, the only connection with their previous interests was the linguistic part of the course (due to their habit of studying in EGP - English for General Purposes courses) and the time of life storytelling. The theory component was new for them and they seemed not to be genuinely motivated by that. They attended the course mostly because it was taught by a native speaker. On the other hand the students expressed thankfulness for opening a new topic for their profession and praised the teacher for relaxed class atmosphere. Only one student indicated that his anxiety during the course became a barrier in his communication.

The feedback emphasized also the importance of learning as a social activity. Up to $86 \%$ students considered learning in a group to be very positive, they appreciated cooperative thinking, group problems solving, helping and encouraging each other. Only $14 \%$ of students would have preferred more individual work. Generally, passivity of some schoolmates had a demotivating effect on other students.

These were just a few results from the research in 2000. Obviously, in the years following, they strongly influenced similar courses at the Faculty of Education in Banská Bystrica. The syllabus designer has been trying to implement all the comments in the revised version of the course, especially the need to build it consistently on a very detailed needs analysis of all the students, diagnosing their linguistic and content pre-knowledge and specifying the input at a higher level in both areas. Also the form of the course was changed, consisting of more interactive 
techniques, cooperation and home project assignments. Each year students' feedback became an important factor of its innovation.

As a lot of effort was put into constructing this ESP course, its author decided to repeat its detailed analysis in yet another investigation in 2015. This predominantly qualitative and much smaller study was intended to analyze some specific factors influencing successful intake. The needs analysis of all 15 attending students was accomplished during the welcome session to this elective course. The reason why the social work students decided to attend it was their genuine motivation to develop both their English language proficiency and their preparedness for their future profession - social work. That they faced no external pressure to take the course was visible in their active participation during the whole course. The students' attendance during the term was decided to be their part of responsibility in their way to reach the expected results. There was no complaint at all about the input orientation, quite the opposite. Several times, students appreciated appreciation for the focus on thinking skills connected with their future profession. As the attendance at this course was a whole social group students' decision, one of its consequences was the uneven level of their linguistic repertoire. Out of 15 students only 2 were at B2 level, most of them at B1+ level and about $20 \%$ at B1- level which was too low for the linguistic input necessary for teaching a professional topic mostly in English. Though this fact was diagnosed in the beginning of the course and the students were warned about potential problems with such unbalanced linguistic prerequisites on their side, they decided to face the problem by trying to help each other and not expecting the same level of grades in the end of the course.

Though observations (action research) and teacher's diary were involved also in this investigation, the main source of data was diary entries written by students several times during the lesson in the beginning and in the end of each lesson as well as after all activities. As these entries were read after each lesson before preparing the next one, this technique proved to be sensitive to students' needs and helped open the way for real learner-centred instruction. This research methodology was complemented by a summative assessment of students' portfolios (consisting of various group/ individual school/home assignments) at the end of the term.

The students were instructed what to focus their diary entries on. The entries in the beginning of the lesson should have focused on their overall setup (affective and volitional dimension: What would I really like to now?), motivation level and learning aptitude. The questions for entries during and after individual activities had two objectives: to find out a) the level of interest and attention given to that particular content and activity input; and b) the awareness of being 'enriched' through that input. These simple instructions were produced to avoid the naturally smooth running of the lesson. Students got used to opening their diaries and writing short entries in short, 23 minute breaks during the teacher's transitions to the next activity. The final entry was a kind of self-evaluation of what they had learnt during that lesson. Here are some interesting results.

The analysis of the entries written immediately after students' arrival at the lesson (which started at 5 p.m.), revealed the current physical, motivational and emotional condition of the students. Especially important was finding out how important for the students was their physical state. In one third of the lessons almost half the students came to the classroom very tired after a long day at school; they reported various physical and mental obstacles to learning such as being tired, being busy with various family issues, being depressed, or needing a cigarette. They were especially thankful for 3 occasions when it was possible to move the lesson to an earlier time of the day, which some found to be "a good thing for our thinking". In all lessons there were about $10-13 \%$ of the attendants feeling some kind of physical 
uneasiness or pain. As so many students were tired at the beginning of the lessons, they were very appreciative of any kind of energizers.

Another unpredicted factor was the influence of the weather. Especially in cases of warm spring weather, up to $100 \%$ of respondents felt more inspired to learn. The students were very active when allowed to learn outside instead of inside the room during a nice sunny day. Except on the one or two sunny days, most times a much smaller proportion of students felt positively (in a good mood, curious, looking forward to lesson, willing to learn or cooperate) than negatively in the beginning of the lesson.

The teacher had to realize all the hindrances that would potentially become obstacles to in the process of language intake if not reflected in the preparation of the lesson. The teacher responded to students' fatigue by offering open access to coffee/tea self-service. Another important move was to focus on a careful choice of energizing activities for the opening of the lesson. These activities could not be too demanding because demanding openings had the potential to increase frustration (as happened in one situation involving a simple Domino activity but rather demanding content). Generally, the students were explicitly thankful for this "learnercentredness" in practice. It helped to create good rapport between the teacher and the students.

After the energizers, the teacher focused on the twofold aims of the course and thus prepared the activities. Though she realised that the students should have had more freedom to choose them, this principle was not well applied in the course. The teacher was very much focused on researching specific topics and thus did not want to be overly influenced by the students' immediate preferences. Instead of that, she tried to introduce the input in a variety of ways - from guessing and matching games involving professional input (e.g: Domino, Call My Bluff) through practical demonstrations and professional problem-solving in groups (brainstorming, mind mapping, Six Thinking Hats, SCAMMPERR, Lotus Blossom) to observing various ideas of professional issues on videos (internet).

In their partial activity entries the students expressed their joy over most of these techniques, the linguistic and content input. They subconsciously commented on the level of its novelty and difficulty. Most of the times they appreciated it, although, as they said, It was demanding, but it was real fun. It was great to learn in English something that will help me in my profession.

The good rapport between the students and the teacher enabled them to share their initial fears and also their criticism on some activities. Several students reported being bored in cases of activities without substantial factual (content) input. Another reason for being bored, explicitly indicated in four cases, was repetition of the specific activity/video, although in one case the student also pointed to an advantage of repeating the same technique (At least we knew the method and could really enjoy the content.) There were also two activities that students reported to be very hard or, better to say, confusing. These difficulties arose because specialized vocabulary was not properly introduced before a new technique using it was implemented. Thus students were not prepared for either the linguistic or the methodological side of the activity. Naturally, in such cases the teacher used codeswitching, considered to be a natural part of bilingual education (more Pokrivčáková, 2014). On one occasion, an activity "left the students sad .... " because of watching a moving video on the impact of bullying on young people. In this case the teacher should have planned watching it not in the end of the day but earlier in the lesson, giving a chance to the students to relieve the sad feeling by discussing it and exploring possible solutions. Without such discussion or follow-up, the input of the lesson depressed the female learners. 
The evaluation of the individual activities involved direct statements from students regarding what caught their attention and what they not only liked but what they opened themselves for and incorporated into their own experience. Notably, they commented on their acquisition of new words (especially focused on their future profession), new ways of thinking and new problem solving techniques, new ways of cooperating, and on the novelty of the various subjects introduced in the input, but also on the appropriate levels of difficulty of the various materials. (It was good that there we faced the challenge to think and express our opinions in English, to concentrate, to communicate and do brainstorming in English, etc. Thinking about professional problems helped me to overcome my tiredness, in the end I felt really fine. I was afraid of this new activity but in the end it was possible to go through it. It was very fast for me but I found out I could understand it, even the difficult Bloom's taxonomy.)

At the end of each lesson, students commented in their journals on the overall intake of that respective lesson. Except for two lessons that received negative evaluations by two students (I am sad because I did not understand some things, it was hard for me. It was hard for me to work in small groups as I do not speak English well, I prefer whole-class activities), all other reflections by all the students were positive, mainly addressing the affective dimension (usually up to $90-100 \%$ wrote I felt very well today/ very pleasant good lesson/ fun/ good atmosphere/ relaxed, no stress/ good people/ learnt a lot/less afraid to speak English/I started to like English/ I appreciate this course because I learnt a lot of ... This was true even in case of feeling tired or ill in the beginning of the lesson (I learnt how to concentrate even when I feel tired). Some students also expressed their decision to change their future approach to learning English and the content that was part of the input ( $I$ will have to study more about this professional method. I really have to start learning English again).

\section{Discussion of Results and Conclusion}

The above two sets of research data from a 15-year period confirmed the range of the most decisive factors in the process of language intake - the precondition of successful learner-centred instruction. The research uncovered the feasibility of this tailor-made ESP course both on macro- and micro- levels.

Evaluated from the macro-level, the research results indicate positive sides as well as shortcomings of both implemented courses. As they were planned as part of a teaching experiment, they were unwittingly more dependent on the teacher's course plan and construction than necessary. Recommendation would be that the dependence upon the teacher should be reduced. The learners should be entrusted with much more free choice, responsibility for their decision-making, and time for feedback and selfreflection during their learning.

Closer analysis ahowed that the teacher should have been more consistent and conscientious regarding the learners' pre-course cognitive level, especially of their linguistic skills and content awareness. In the case of the first course, the nativespeaking teacher was so "foreigner-aware" that her linguistic input was at a lower level than probably of her students. On the contrary, the second course was aimed at $\mathrm{C} 1$ level but most of the learners' entrance foreign language proficiency was between $\mathrm{B} 1$ and $\mathrm{B} 1+$. Though in the beginning of this course they were very highly motivated (having rather unrealistic linguistic expectations), their linguistic skills lagged behind their ambitions. Subconscioiusly, they may have expected the teacher to achieve their goals for them and to manage their own learning. The prospects for success were thus not very good, taking into account the fact that they even had problems with 
comprehending more complex instructions ( 2 students gave up the whole course after the first session).

As the courses were aimed at teaching how to develop their linguistic as well as thinking skills, their students did not benefit from mere metacognitive information about techniques and methods, they expected to learn them directly during executing meaningful, authentic activities. In fact, university language learners are very sensitive to the level of intellectual authenticity and novelty of the language input (also Sousa, 2006: 28-30). If the information gap is missing, the input remains unused and the teacher's energy waisted.

The continuous process of writing diary entries also confirmed another important affective factor - the learner's need to feel self- confidence about mastering the new material that they are learning (Brown, 2001, pp. 61-62). Due to the adult learners' pedagogical and psychological frame, as well as to their individual learning styles (Hanesova, 2003: 77-79), freedom and autonomy to chose the content of learning, learning methods, and the means of assessment has critical value in adult language learning. The input has to be focused on solving problems and on the development of students' capacity for critical thinking, encouraged by advance organizers and visualisations (e.g. mind maps). In comparison with children, adults are much more stressed and concerned with their learning. Though stress did not seem to be a significant hindrance in students' learning in any of the mentioned courses, none of them succeeded in offering the students a true, objective sense of accomplishment. Their input expectations were either too low or too high, always resulting in a tendency to lower students" motivation. "People cannot stay motivated unless they experience some success.” (Zull, 2002: 238).

We found out that the learning environment supporting successful language intake by the adult students has to be rich not only in their meaningful content and linguistic input, but especially in positive affective incentives and opportunities for cooperative, non-competitive learning. The intake is also enhanced if visual aids, especially graphic organizers, are included. Though up to this point this insight has been emphasized predominantly with reference to children as young learners, adult language learners tend to respond especially enthusiastically to any positive step towards treating them as adult humans with their own interests and joys, fears and ambitions, reflecting the late time of the day and their possible tiredness, pain, etc. They are very aware and thankful for the tireless effort of teachers to activate their learning by such means as brainstorming, case studies, discussions, problem solving, and mind mapping, all of which have a greater prospect of achieving learning success than teacher's lecturing or doing textbook exercises.

\section{Bibliographic references}

ALLEN, M. J. 2004. Assessing Academic Programs in Higher Education. Bolton: Anker Publ. Comp. ISBN 978-1882982677.

ANDERSON, L. - KRATHWOHL, D. 2001. A Taxonomy of Learning. Teaching and Assessing: A Revision of Bloom's Taxonomy. New York: Longman Publishing. ISBN 978-0321084057.

AUSUBEL, D. P. - NOVAK, J. D. - HANESIAN, H. 1978. Educational Psychology: A Cognitive View. New York: Holt, Rinehart and Winston Inc.

BIROVA, J. 2013. About Theoretical Definitions of Pluralistic and Pluricultural Approaches. In: XLinguae, European Scientific Language Journal, vol 6, issue 2, pp. 91-103.

BROWN, H. D. 2001. Teaching by Principles: An Interactive Approach to Language Pedagogy. 2 nd ed. New York: Longman. ISBN 9780130282835.

CAROLL, S. 2001. Input and Evidence the Raw Material of Second Language Acquisition. Amsterdam: John Benjamins. ISBN 158811011 
CHAUDRON, C. 1983. Simplification of Input: Topic reinstatements and their effect on L2 learners' recognition and recall. In TESOL Quarterly, 17, pp. 437-458.

Communique of the Conference of European Ministers Responsible for Higher Education, Leuven and Louvain-la-Neuve, 28-29 April 2009.

CORDER, S. P. 1967. The Significance of Learner's Errors. International Review of Applied Linguistics, No 5, p. 161-170. According to: Rast, R. (2008). Foreign Language Input: Initial Processing. Clevedon Hall: Multilingual Matters, p. 3. ISBN 9781847690418.

CRUMLY, C. 2014. Pedagogies for Student-Centered Learning: Online and OnGround. Minneapolis: Augsburg Fortress. ISBN 978-1-4514-8945-3.

DALE, L. - VAN DER ES, W. - TANNER, R. 2011. CLIL Skills. Leiden: Universiteit Leiden. ISBN 978-90-70910-50-1.

FLEMING, W. 1987. Students Learning Work - Grounds for An In Situ Analysis. In Instructional Science, 16, pp. 109-122.

GAGLIARDI, A. C. 2012. Input and Intake in Language Acquisition. (Dissertation thesis). Maryland: University of Maryland.

GEVEN, K. - ATTARD, A. 2012. Time for Student-Centred Learning? In Curaj, A.; Scott, P.; Vlasceanu, L. (eds.). European Higher Education at the Crossroads. London: Springer. ISBN 9400739370

HANESOVA, D. 2003. Odborna anglictina na pedagogickych fakultach. Banska Bystrica: PF UMB. ISBN 80-88945-67-4

HANESOVA, D. 2014. From Learning Facts to Learning to Think. Banska Bystrica: PF UMB. ISBN 978-80-557-0655-9.

HATCH, E. 1983. Psycholinguistics: A Second Language Perspective. Rowley: Newbury House. According to: Rast, R. Foreign Language Input: Initial Processing. Clevedon Hall: Multilingual Matters, 2008, p. 3. ISBN 978-1-84769041-8.

HORVATHOVA, B. 2011. Rozvoj kompetencii autonomneho studenta vo vyucovani odborneho jazyka pomocou e-learningu. In: Xlinguae Journal, Vol. 4, Issue 1, January, pp. 27-33.

HUBA, M. E. - FREED, J. E. 2000. Learner-Centered Assessment on College Campuses: Shifting the focus from teaching to learning. Needham Heights, MA: Allyn \& Bacon. ISBN 978-0205287383.

HUITT, W. 1999. Conation as an important factor of mind.Educational Psychology Interactive. Valdosta : Valdosta State University.

KEMBER, D. 2009. Promoting Student-Centered Forms of Learning across an Entire University. Higher Education, 58, No. 1, p. 1-13.

KRASHEN, S. 1982. Principles and Practice in Second Language Acquisition. Oxford: Pergamon Press.1 st internet edition, July 2009. ISBN 0-08-028628-3.

KUMARAVADIVELU, B. 1994. The Postmethod Condition: (E)merging Strategies for Second/Foreign Language Teaching. In TESOL Quarterly, Vol 28, No. 1. Spring, pp. 27-48.

McCOMBS, B. L. 2003. Defining Tools for Teacher Reflection: The Assessment of Learner-Centered Practices. Report for American Educational Research Association. Denver: University of Denver Research Institute.

NUNAN, D. 1996. The Learner-Centred Curriculum. Cambridge: CUP. 195 p. ISBN 978-052135843.

PAWLAK, M. 2011. Second Language Learning and Teaching. German: Springer. 43 p. ISBN 978-3-642- 20849-2.

PILLAR, G. W. (n.d.). A Neuroscientific Perspective of Language Processing in Transforming Input into Intake. (Doctoral Dissertation unpublished). University Colleage of Nyiregyhaza. 
POKRIVCAKOVA, S. 2014. Code-switching ako lingvodidakticky fenomen. In Xlinguae Journal, Vol. 7, Issue 2, April, pp. 61-74.

POLOK, K. 2014. Bilingvalny ucitel alebo o utrapach vyucovania cudzich jazykov. In Xlinguae Journal, Vol. 7, Issue 3, June, pp. 17-31.

PUTZ, M. - SICOLA, L. 2010. Cognitive Processing in Second Language Acquisition. Amsterdam: John Benjamins Publishing. 373 p. ISBN 9789027288325.

RAST, R. 2008. Foreign Language Input: Initial Processing. United Kingdom: Cromwell Press limited. ISBN 978-184769-0418

REINDERS, H. 2012. Towards a Definition of Intake in Second Language Acquisition. In Applied Research in English, 1(2), pp. 15 - 36.

SATO, E. - JACOBS, B. 1992. From Input to Intake: Towards a brain-based perspective of selective attention. In: Issues in Applied Linguistics, 3(2), 1992, pp. 267-292.

SHARWOOD SMITH, M. 1993. Input Enhancement in Instructed SLA: Theoretical Bases. In Studies in Second Language Acquisition, 15, p. 165-179.

SOUSA, D. A. 2006. How the Brain Learns. 3 rd ed. Thousand Oaks: Corwin Press. 309 p. ISBN 978-1-4129-3661-3.

Student Centred Learning. In Bologna Process - European Higher Education Area. 2015. Website:www.ehea.info.

Time for a paradigm shift: Student Centred Learning Final Report. European Student Union, 2011.

TROSBORG, A. 1995. Interlanguage Pragmatics: Requests, Complaints and Apologies. Berlin: De Gruyter. ISBN 9783110144680.

WEIMER, M. 2012. Learner-Centered Teaching. Five Characteristics of LearnerCentered Teaching. San Francisco: Jossey-Bass. 243 p. ISBN 978-1118-119280.

VANPATTEN, B. 2002. Processing instruction: an update. Language Learning, 52(4), pp. 755-803. In Reinders, H. (2012). Towards a Definition of Intake in Second Language Acquisition. In Applied Research in English, 1(2), pp. 15 - 36.

VASBIEVA, D. G. 2015. Teaching Strategy on Learning English Phrasal Verbs by Economics Major Students in Russia. In: Xlinguae Journal, Vol. 8, Issue 3, June, pp. 57-65.

ZELENKOVA, A. 2015. Particularities of English for Specific Purposes and Development of Intercultural Competence. In Xlinguae Journal, Vol. 8, Issue 1, January, pp. 36-49.

ZULL, J. E. 2002. The Art of Changing the Brain. Sterling: Stylus Publishing. 262 p. ISBN 978-1579-220549.

ZULL, J. E. 2004. The Art of Changing the Brain. In The Educational Leadership, vol 62, No. 1, pp. 68-72.

The research presented in this study was supported by the project Mobility Enhancing Research, Science and Education at the Matej Bel University - Activity 4 ITMS code: 26110230082, under the Operational Program Education co-financed by the European Social Fund.

Words: 8107

Characters: 53521 (29, 74 standard pages)

Assoc. Prof. PaedDr. Dana Hanesová, PhD.

Faculty of Education, Matej Bel University

Ružová 13, 97411 Banská Bystrica

Slovakia

dana.hanesova@umb.sk 